\title{
Genetic Alteration of Legume Seed Proteins
}

\author{
Fredrick A. Bliss \\ Department of Pomology, University of California, Davis, CA 95616
}

\section{INTRODUCTION}

Grain legumes are a major source of dietary fiber. protein, and calories, and they are especially important where consumption of animal proteins is precluded because of inaccessibility. poverty, or dietary preferences. In addition to high protein concentration, some grain legumes contain large amounts of oils that are important for food and industrial uses (Norton et al., 1985).

Despite being rich in proteins, which may account for up to $40 \%$ of the dry matter in the seeds, grain legumes often do not contribute as fully as expected to the protein needs of humans and domesticat ed animals. The proteins in grain legumes are considered to be dietetically inferior because of low concentrations of sulphur-amino acids, poor digestibility, and the presence of antinutritional factors, some of which are proteins. Additionally, grain legumes show quite variable productivity, with low yields being common and response to improved cultivation practices being unpredictable. Although capable of symbiotic nitrogen fixation with appropriate rhizobia. most grain legumes do not fix nearly enough nitrogen to satisfy the needs for plant growth and full maturation of large quan tities of protein-rich seeds.

Based on these general attributes of grain legumes and recognizing that they vary in degree both inter- and intraspecifically, several objectives for nutritional improvement can be stated. These include, 1) enhancement of protein nutritional quality by increasing the levels of limiting essential amino acids, improving digestibility, and lowering anti-nutritional factors; 2) improving the culinary properties of seeds, especially after periods of prolonged storage; 3 ) altering physical and chemical properties to enhance use in new innovative ways; and 4) improving yield potential concurrently with protein quantity and quality enhancement. Some progress toward attaining these objectives has been made by using classical breeding and selection, and by improved processing of food products. Recombinant DNA-based methods are becoming available for use in altering important properties of proteins and attributes of grain legumes related to proteins in ways not before feasible. If improvements can be coupled with greater productivity, the dietary contributions of grain legumes will be increased significantly.

\section{BIOLOGICAL PROPERTIES OF LEGUME SEED PROTEINS}

The protein concentration in grain legume seeds ranges from about $18 \%$ to $40 \%$, with large variation among species and signifi cant genetic variation among cultivars within a species. Globulins, which are the major storage proteins, account for $\sim 70 \%$ of the total, with glutelins, albumins, and free amino acids making up the remainder (Norton et al., 1985). The total seed protein is constituted by many different proteins rather than being homogenous. Each of the proteins has different chemical and physical properties that contribute particular attributes; i.e , amino acid composition, digestibility, toxicity etc., and they are controlled by specific genes and gene families. The studies by Mertz et al. (1964) of the op-2 endosperm mutant of maize demonstrated that major seed storage proteins can be altered genetically, with concomitant affects on amino acid com position that are due to changes in the relative amounts of constituent proteins.

Osborn (1988) has stated “... the bean seed, as a biological unit, represents an excellent model for investigations on development and gene regulation. Unlike secondary products, seed proteins are encoded directly by structural genes. They can be identified easily, distinguished qualitatively. and quantified. Seed proteins are synthesized in large quantities and in a specific tissue during a distinct developmental time period. These properties have allowed researchers to address questions of genetic regulation that are more difficult to address in other systems. Studies on the genetic control of bean seed proteins have provided both an understanding of basic biological phenomena and information that can be used to improve an important dietary protein." Because of these attributes, the genetic control of seed proteins has been studied extensively and is well-understood at different levels of organization and expression. Great variation in the seed protein expression can be tolerated in legumes, with seeds that have markedly different amounts of the important constituent proteins being viable and producing plants with normal appearance, e.g., the phaseolin-deficient phenotype of Phaseollls coccineus L. and P. vulgaris L. (Gepts and Bliss, 1984).

\section{CLASSICAL GENETICS AND PLANT BREEDING}

Increased seed protein concentration

Although the seeds of grain legumes are rich in protein compared to those of most other food staples. it is important to at least maintain or increase those levels of protein as other changes are made, e.g., increased seed yields. When seeds are eaten directly as opposed to being a source of industrial protein, protein intake usual ly reflects quantity of seeds eaten rather than consumption until pro tein demands are met. Since the quantity eaten is usually limited by availability. income level. body size and age. etc., it is advantageous to have high concentrations of good-quality, digestible protein in those seeds.

In most grain legumes there is substantial genetic variability for expression of genes that control protein synthesis and accumulation. Despite the widely held notion that negative relationships among percentage seed protein, yield, and amino acid composition of protein preclude simultaneous improvements of these traits, changes through breeding have been made. Often the negative correlations are relatively small (Leleji et al., 1972; Kelly and Bliss, 1975; Mutschler and Bliss. 1981; Evans and Gridley, 1979). and if the basis of these correlations is known. successful straregics can be used to prevent reduction in one trait as another is improved (Bliss and Brown, 1983).

Increased percentage of total protein measured on a dry-weight basis can result from decreased nonprotein (i.e., starch), increased proteins, or a combined change without a concomitant change in seed size. Lower seed yields have sometimes resulted from selection solely for increased percentage of protein if the effects on the seed size or constituent seed fractions are not considered (Bliss and Brown. 1983). However. identification of common bean breeding lines with increased amount of phaseolin per seed has facilitated obtaining increased percentage protein without lower yields. Intercrossing superior inbred backcross lines produced progenies with even higher levels of phaseolin and increased seed protein concentration than that of the parents (Hartana, 1986).

Delaney (1988) reported substantially higher phaseolin and total protein concentrations following recurrent selection for phaseolin 
percentage in a population of white beans segregating for genes with either major or small effects on expression of specific proteins. Selection for alleles associated with increased amounts of phaseolin using electrophoretic identification also was effective for producing superior high protein lines without loss of yield potential.

Soybean seed yields generally exceed those of common bean even though soybean seeds contain much higher protein concentrations and also $\approx 15 \%$ oils. Although usually there are negative correlations among these traits. with the strongest being between per centage of protein and oil. selection for either increased protein per centage or higher yields need not necessarily accompany reduced levels of the other trait if suitable selection strategies are practiced. When precaution is taken to preclude selection of seeds with higher protein concentration due to reduced concentrations of other constituents (e.g., either starch or oil), increased protein concentration need not be at the expense of lower yields. When it is possible to do so, high-protein cultivars should be developed. especially for direct human consumption.

\section{Altered amino acid composition}

Globulins are the predominant proteins in the seeds of most grain legumes (Danielsson. 1949). with the suboptimal amino acid composition being due to inadequate methionine and cystine. The principal globulins are the so-called lepumin (11S). vicilin (7S) and, in pea, faba, and soybean, small amounts of convicilin. The overall concentrations of amino acids reflect the concentrations in each fraction and the relative amount of each protein fraction in the seed. Although richer in the limiting sulfur amino acids, glutelins (10\% to $20 \%$ ) and albumins (10\% to $10 \%)$ do not constitute enough to over come the low-sulfur amino acid levels of the predominant globulins.

The high-lysine trait in cereals such as maize, sorghum. and bar ley results from the genetic suppression of the lysine-poor endosperm proteins. in favor of increased amounts of other proteins rich in lysine and other basic amino acids (Axtell, 1981). Often those mutant alleles alter other properties of the endosperm that cause seed-related problems, i.e., lighter kernels, lower yield, etc. that must be improved before new cultivars are acceptable. Although mutant alleles with effects on amino acid composition as profound as those produced by the cereal endosperm mutants have not been identified in grain legumes, some mutant alleles of legumes dramatically alter the quantity of certain protein fractions. A mutant allele associated with the absence of phaseolin (7S) in the $P$. coccineus cv. Mexican Red runner causes complete elimination of that protein in the original cultivar and when transferred to lines of $P$. vulgaris (Gepts and Bliss, 1984). Percentage total protein is unaffected, with increased amounts of other proteins apparently being produced. Although the enhanced proteins have not yet been identified. they likely contain less sulfur amino acids, since there was less available methionine in phaseolin-deficient seeds than in normal ones (Gepts and Bliss, 1984). Attempts to enhance the methionine-rich polypeptides of bean identified by Apostolatos (1984) have not yet been successful, even in the phaseolin-deficient lines.

In bean lines containing the lectin-like protein arcelin, there were reduced amounts of phaseolin and less available methionine (Gepts and Bliss. 1984). Arcelin contains less sulphur amino acids than phaseolin. but more than other bean lectins (Osborn et al., 1988). Since phaseolin appears to contain the most sulfur amino acids among the major proteins of common bean, Gepts and Bliss (1984) suggested that selection for increased phaseolin would be desirable in current materials. Inbred backcross breeding lines with more phaseolin per seed showed higher levels of available methionine (Gepu and Bliss, 1984). and the selections of Delaney (1988). which have greatly enhanced phaseolin relative to other proteins. should provide useful breeding materials.

Two soybean cultivars contain variant alleles that result in the accumulation of lesser amounts of 7S subunits and of total 7S globulin protein (Ogawa et al., 1989). They reported that the subunit variation resulted in higher amounts of sulfur amino acids than in usual cultivars because of reduced levels of the sulfur-poor $7 \mathrm{~S}$ globulin and a corresponding increase in $11 \mathrm{~S}$ globulin. which contains more sulfur amino acids. In four lines with small amounts of $7 \mathrm{~S}$, sulfur amino acids were increased by $20 \%$ and total protein was similar to levels found in usual cultivars.

There is substantial variability in the grain legumes for either enhanced or reduced levels of important seedprotein fractions, but the variability for fractions with greatly increased sulfur amino acid concentration may not be great enough to achieve the increases required to produce greatly improved protein nutritional quality.

\section{Improved digestibility and culinary properties}

Digestibility is especially important in the grain legumes consumed directly. All food legumes must be cooked to soften the seeds for greater palatability and to inactivate heat-labile toxic compounds such as protease inhibitors and phytohemagglutinins. Ease of preparation related to soaking and cooking time is important for processed bean products as well as those prepared in traditional ways. Unless the seeds possess inherently impermeable testae, newly harvested seeds usually require relatively short-term soaking and cooking. Seed aging and intensification of the hard shell or "bud-to-cook" phenomenon often lengthen the preparation time and reduce the value of stored beans (Sgarbieri and Whitaker, 1982: Jones and Boulerer. 1983). Long cooling time is especially important in areas where energy is scarce and/or expensive. The genetic basis of these undesirable traits associated with aging and increased cooking time is not well-known.

Poor protein digestibility usually is though to be due to a combi nation of resistance of a particular protein structure to denaturation and protease activity. inadequate amounts of essential amino acids, incompletely denatured lectins and protease inhibitors. and the presence of compounds that form insoluble complexes with proteins, e.g., tannins and phytates (Sgarbieri and Whitaker. 1982). Unheated phaseolin, the predominant protein of bean, is particularly resistant to protease activity (Romero and Ryan, 1978). and even with heat treatment some resistance remained. The phaseolin-deficient bean lines developed from the cross with the $P$. coccineus cultivar lacking phaseolin would be interesting to test for improved digestibility.

Lectin-deficient phenotypes have been described in common bean (Brucher, 1968; Osborn, 1988) and soybean (Orf et al., 1978). but, under adequate cooking conditions. little differences in digestibility is found. Where beans are difficult to cook thoroughly because of high altitude or inadequate energy, and toxic substances are not completely inactivated, lectin-deficient seeds may be superior. Considerable variability in the presence of protease inhibitors and the active form present has been found in soybean. The occur rence of a null phenotype (Orf and Hymowitz 1979) allows for development of cultivars without presence of the Kunitz trypsin inhibitor). Only recently has the presence of tannins in testae of bean seeds been related to reduced protein digestibility, although their effects are well-known in other crops (e.g. sorghum), and coloredseeded beans usually show lower protein digestibility than whiteseeded ones (Norton et al., 1985). Genetic differences in testae tannin content have been reported in bean (Ma and Bliss, 1978) and in Vacia faba (Bond et al.. 1985).

The consumption of some grain legumes is related to intestinal discomfort from flatulence and gastrointestinal hypersensitivity (Norton et al.. 1985). Oligosaccharides in the bean seed are thought to be responsible for gas production in sensitive individuals, but the exact causes are not known, despite previous extensive studies. Hosfield et al. (1989) reported that gas production in in vitro tests was related to several indigestible components of the bean seed. The hypersensitivity to bean shown particularly by children and infants has been related to presence of lectins (Norton et al., 1985); therefore, the lectin-deficient seeds may be important in reducing this problem. 


\section{Insect resistance related to seed proteins}

Grain legume crops are attacked by many pests, with seed-dam aging insects. including the bruchids, causing extensive damage (Labeyrie, 1981). Although bruchids are commonly referred to as stored grain insects, infestation often occurs in near-maturity in the field and the insects pass through several cycles during storage. These insects are found worldwide. with damage ranging from nil to nearly complete losses during long-term storage.

Many natural compounds, including some seed proteins, have insecticidal properties. Jansen et al. (1976) showed that bean lectins added to artificial seeds made from cowpea flour increased the mortality of cowpea weevil (Callosobruchus maculatus) in feeding tests. However, this weevil is not a usual pest of common bean. After failing to find resistance to common bean weevil, Acanthoscelides obtectus, and Mexican bean weevil, Zabrotes subfasciatus, in the world bean collection at the Centro International de Agricultura Tropical (CIAT). Schoonhoven et al. (1983) reported resistance in wild bean accessions. Subsequently, resistance to $Z$. subfasciatus and, to a lesser degree, A. obtectus, has been shown to be due to the lectin-like protein arcelin (Osborn et al.. 1988). Unlike some other proteins with insecticidal properties, arcelin constitutes a large portion of the storage protein when expressed. and a concomitant reduction in phaseolin is seen (Romero Andreas et al. 1986). Although total protein concentration in arcelin-containing seeds is comparable to those without arcelin (Gepts and Bliss, 1984; Romero Andreas et al., 1986). the available total mathionine is reduced because arcelin contains less methionine than phaseolin (Osbom et al., 1988). Knowledge of the basis of bruchid resistance allows more efficient transfer of resistance alleles into adapted cultivars (Hannsen, 1989). with an opportunity to minimize undesir able correlated effects on yield and protein traits.

In cowpea, Gatehouse et al. (1979) suggested that resistance of cultivar TVu 2027 to Callosobruchus maculatus was due to trypsin inhibitors in the seeds. Other cowpeas with high levels of trypsin inhibitors have not shown resistance, and, recently, Xavier-Filho et al. (1989) reported no positive relationships among resistance proteinase inhibitory action and levels of lectins and tannins.

Despite the considerable genetic variability for many of the traits associated with protein quantity and quality of legume protein, there have been only modest attempts to improve nutritive value through breeding (Evans and Gridley 1979). This is due largely to the limited resources available for conducting research and to higher priority given 10 breeding for increased yield and increased resis tance.

\section{OPPORTUNITIES THROUGH GENETIC ENGINEERING}

The extensive knowledge about the molecular properties of seed storage proteins contributes to understanding the regulation of gene expression and to the ability to manipulate expression through genetic transformation. Many of the important legume seed proteins have been well-characterized because of their abundance, tissue- or organ-specificity, and well-defined temporal regulation (Brown et al., 1982). The bean phaseolin genes were among the first plant genes to be expressed in transgenic plants (Murai et al., 1983). and since then there have been numerous studies in which bean protein genes have been expressed in heterologous plant systems. The nat ural variants that alter the bean protein expression and unique protein genes horn other plants will provide useful materials for genet ic engineering of legume seed proteins.

Genetic engineering methods could be used for altering protein composition in several-ways (Osborn, 1988): Foreign genes encod ing seed proteins with nutritionally improved amino acid composi tion or better digestibility, and other genes for proteins that nutritionally compliment phaseolin protein could be introduced. One such protein that has been mentioned is a Brazil nut protein that has a high sulfur-containing amino acid content (Altenbach et al., 1987). Another approach might be to change the amino acid com- position of phaseolin, by altering the nucleotide sequence of a phascolin gene(s) to include more methionine residues, then to transform the phaseolin-deficient line with the altered gene.

The demonstration that gene products can be reduced or elimi nated through the expression of anti-sense RNA provides another approach to reducing less-desirable proteins. Since, when certain proteins in bean and soybean seeds are decreased. some other proteins are increased. this may be a way to increase the overall nutri tional value. In recent studies in grain legumes, regulatory sequences of DNA that control expression of the seed protein genes have been identified (see e.g.. Riggs et al., 1989a; 1989b; Allen et al., 1988; Chen et al.. 1988; Higgins et al., 1988; Shirsat et al.. 1989).

A major obstacle to the use of genetic engineering for altering the seed proteins of grain legumes continues to be lack of a reliable genetic transformation system. It has been particularly difficult to regenerate plantlets from various tissue sources, as is being done routinely in some plants; e.g., of the family Solanaceae. Even though transgenic legume plants cannot yet be obtained routinely, there have been some reports of success in legumes, including grain legumes and their relatives. The successful methods reported include: use of Agrobacterium tumefaciens for gene transfer, followed by the assay of various reporter genes to aid in identifying putative transformants; production of hairy roots following transfor mation with $A$. rhizogenes. then regeneration of transformed plantlets from root cultures (Rech et al., 1989); and insertion of DNA into the nucleus of meristem cells by use of particle acceleration, then identification of putative transformed sectors and production of transformed seeds on those sectors (McCabe et al., 1988). If a suitable. efficient transformation system can be developed, alteration of legume seed proteins via genetic engineering will likely progress rapidly because there is considerable knowledge about the molecular properties of these proteins already available.

\section{CONCLUSION}

Grain legumes are important sources of protein in the diets of many people, and the crops fit well in very different cropping sys tems worldwide. Since legumes are used extensively either directly or as protein-rich foods and feeds after processing, improvement of protein quantity, quality, and digestibility could significantly enhance the dietary value. There is much natural genetic variation for seed protein expression, with mutant alleles known that either increase or decrease the synthesis and accumulation of specific proreins. The relative amounts of the constituent fractions affect the total protein concentration and the amino acid composition as well as digestibility and physical properties. Although breeding for improved seed protein traits has not been pursued extensively, selec tion has been shown to be effective for improving protein concentration and quality without concomitant reduction of yield and modification of other essential traits. Molecular properties of seed proteins have been studied extensively. providing a broad information base for manipulation via genetic engineering. Rapid progress can be made if a reliable, efficient systems of genetic transformation can be developed for grain legumes.

\section{Literature Cited}

Allen, R.D.. P.A. Lessard. and R.N. Beachy. 1988. Interaction of nuclear proteins with ß-conglycinin gene. upstream sequences. J. Cell Biochem. Suppl. C12:223. (Abstr.)

Allenbach, S.B., K.W. Pearson, F.W. Leung, and S.M. Sun. 1987. Cloning and sequence analysis of a cDNA encoding a Brazil nut protein excep tionally rich in methionine. Plant Mol. Biol. 8:239.

Aporiolalos. G. 1984. Isolation and characterization of a methionine-rich protein from edible dry bean (Phaseolus vulgaris L.). Plant Sci. Lett. 33:39-46.

Axtell. J.D. 1981. Breeding for improved nutritional quality. p. 365- 432. In: KJ. Frey (ed.). Plant breeding Il. Iowa State Univ. Press, Ames. 
Bliss, F.A. and J.W.S. Brown. 1983. Breeding common bean (Phaseolus vulgaris L.) for improved quantity and quality of seed protein, p. 59-102. In: J. Janick (ed.). Plant breeding reviews. AVI, Westport, Conn.

Bond, D.A.. D.A. Lawes, G.C. Hawtin, M.C. Saxena, and J.H. Stephens. 1985. Faba bean (Vicia faba L.), p. 199-265. In: R.J. Summerfield and E.H. Roberts (eds.). Grain legume crops. Collins, London.

Brown, J.W.S., D.R. Ersland, and T.C. Hall. 1982 Molecular aspects of storage protein synthesis during seed development. p. 342. In: A. Khan (ed.). The physiology and biochemistry of seed development. dormancy and germination. Elsevier, New York.

Bruchcr, O. 1968. Absence of phytohemagglutinin in wild and cultivated beans from South America. Proc. Trop. Reg. Amer. Soc. Hort. Sci. 12:68-85.

Chen, Z.-L, N-S. Pan and R.N. Beachy. 1988. A DNA sequences element that confers seed-specific enhancement to a constitutive promoter. EMBO J. 7:297-302.

Danielsson, C.E. 1949. Seed globulins of the Granineae and Leguminoseae. Biochem. J. 44:387-100.

Delaney, D.E. 1988. Selection methods for increasing percentage phaseolin in seeds of common bean (Phaseolus vulgaris L) using seed protein markers. PhD Diss., Univ. of Wisconsin, Madison.

Evans, A.M and H.E. Gridley. 1979. Prospects for the improvement of protein and yield in food legumes. Current Adv. Plant Sci. 32:1-17.

Gatehouse. A.M.R.. J.A. Gatehouse. P. Dobie, A.M Kilminister. and D. Boulter. 1979. Biochemical basis of insect resistance in Vigna unguiculata. J. Sci. Food Agr. 30:948-958.

Gepts, P.L and F.A. Bliss. 1984. Enhanced methionine concentration associated with higher phaseolin levels in common bean seeds. Theor Applied Genet. 69:47-53.

Hannsen. R.L.H. 1989. Bruchid resistance and agronomic traits of cultivated bean lines (Phaseolus vulgaris L) containing arcelin seed protein alleles from wild beans. PhD Diss., Univ. of Wisconsin, Madison.

Hartana, A. 1986. Components of variability for seed protein of common bean (Phaseolus vulgaris L.). PhD Diss., Univ. of Wisconsin, -Madison.

Higgins, T.J.V., E.J. Newbigin. O. Spencer, D.J. Llewellyn, and S. Craig. 1988. The sequence of a pea vicilin gene and its expression in transgenic tobacco seeds. Plant Mol. Biol. 11:683-695.

Hosfield, G.L., M.R. Bennink, R.A. Thompkinson, and MA. Uebersax 1989. Gas potentials from fermentation of indigestible seed components of dry beans. HortScience 24:90. (Abstr.)

Jansen, D.H.. H.B. Juster, and I.E. Liener. 1976. Insecticidal action of the phytohemagglutinin in black beans on a bruchid beetle. Science 192:795-796.

Jones, P.M.B. and D. Boulter. 1983. The cause of reduced cooking rate in Phaseolus vulgaris following adverse storage conditions. J. Food Sci. 48:623-626

Kelly, J.D. and F.A. Bliss. 1975. Heritability estimates of percentage seed protein and available methionine and correlations with yield in dry beans. Crop Sci. 15:753-757.

Labeyrie, V. 1981. Ecological problems arising from weevil infestation of food legumes. p. 1-15. In: V. Labeyrie (ed.). The ecology of bruch-ids attacking legumes (Pulses). Junk. London.

Leleji. O.I.. M.H. Dickson, L.V. Crowde, and J.B. Bourke. 1972. Inheritance of crude protein percentage and its correlation with seed yield in beans, Phaseolus vulgaris L. Crop Sci. 12:168-171.

Ma, Y. and F.A. Bliss. 1978. Tannin content and inheritance in common bean. Crop Sci. 18:201-209.

McCabe, D.E., W.F. Swain, B.J. Martinelli. and P. Christou. 1988. Stable transformation of soybean (Glycine $\max$ ) by particle acceleration. Biotechnology 6:923-926

Mertz, E.T., L.S. Bates, and O.E. Nelson. 1964. Mutant gene that changes protein composition and increases lysine content of maize endosperm. Science 145:279-280.

Murai, N.. D.W. Sutton, MG. Murray. J.L Slighton. D.J. Merlo. N.A. Reichen, C. Sengupta-Gopalan, C.A. Stock, R.F. Barker. J.D. Kemp, and T.C. Hall 1983. Phaseolin gene from Bryan is expressed after transfer to sunflower via tumor-inducing plasmid vectors. Science 222:476.

Murschler, M.A. and F.A. Bliss. 1981. The inheritance of bean seed globulin content and its relationship to protein content and quality. Crop Sci. $21: 289-294$

Norton. F.. F.A. Bliss, and R. Bressani. 1985. Biochemical and nutritional attributes of grain legumes, p. 73-114. In: R.J. Summerfield and E.H. Roberts (eds.). Grain legume crops. Collins, London.

Ogawa, T., E. Tayama. K. Kitamure, and N. Kaizuma. 1989. Genetic improvement of seed storage proteins using three variant alleles of $7 \mathrm{~S}$ globulin subunits in soybean (Glycine $\max$ L). Jpn. J. Breed. 39:137-147.

Orf, J.H., T. Hymowitz. S.P. Pull, and S.G. Puepke. 1978. Inheritance of a soybean seed lectin. Crop Sci. 18:899-900.

Osborn, T.C. 1988. Genetic control of bean seed protein. CRC Crit Rev. Plant Sci. 7:93-116.

Osbom, T.C., M. Burow. and F.A. Bliss. 1988. Purification and characterization of arcelin seed protein from common bean. Plant Physiol. 86:399-405.

Osborn, T.C., D.C. Alexander. S.S.M. Sun, C. Cardona, and F.A. Bliss 1988. Arcelin is a lectin-homologous seed protein that confers insect resistance. Science 240:207-210.

Rech, E.L., T.J. Golds, T. Husnain, M.H. Vainstein. B. Jones, N. Hammatt, B.J. Mulligan. and M.R. Davey. 1989. Expression of a chimaeric kanamycin resistance gene introduced into the wild soybean Glycine canescens using a cointegrate Ri plasmid vector. Plant Cell Rpts. 833-36.

Riggs. D.C.. D.C. Hunt. J. Lin. and M.J. Chrispeels. 1989. Utilization of luciferase fusion genes to monitor differential regulation of phytohemagglutinin and phaseolin promoters in transgenic tobacco. Plant Sci. 63:47-57.

Romero, J.D. and D.S. Ryan. 1978. Susceptibility of the major storage protein of the bean Phaseolus vulgaris $\mathrm{L}$ to in vitro enzymatic hydrolysis. J.. Agr. Food Chem. 26:784-788.

Romero Andreas, J., B.S. Yandell, and F.A. Bliss. 1986. Bean arcelin I: Inheritance of a novel seed protein of Phaseolus vulgaris L. and its effect on seed composition. Theor. Applied Genet. 72:123-128.

Schoonhoven, A.V., C. Cardona, and J. Valor. 1983. Resistance to the bean weevil and the Mexican bean weevil (Coleoptera:Bruchidae) in non-cultivated common bean accessions. J. Econ. Entomol. 76: 1255-1259.

Sgarbieri. V.C. and J.R. Whitaker. 1982. Physical, chemical and nutritional properties of common bean (Phaseolus) proteins. Adv. Food Sci. 28:93-166.

Shirsat. A., N. Wilford. R. Croy. and O. Boulter. 1989. Sequences responsible for the tissue specific promoter activity of a pea legumin gene in tobacco. Mol. Gen. Genet. 215:326-331.

Xavier-Filho, J., F.A.P. Campos. M.B. Ary, C.P. Silva, M.M.M. Carbalho, M.LR. Macedo. F.J.A. Lemos. and G. Grant. 1989. Poor correlation between levels of proteinase inhibitors found in seeds of different cultivars of cowpea (Vigna unguiculata) and the resistance/susceptibility to pre dation by Callosobruchus maculatus. J. Agr. Food Chem. 37:1139-1143. 